\title{
The Meaning and Operation of the European Convention \\ for the Protection of Human Rights \\ and Fundamental Freedoms and the Judgments \\ of the European Court of Human Rights \\ in the Legal System of the Russian Federation
}

\author{
Valentina V. Tereshkova* \\ Siberian Federal University \\ 79 Svobodny, Krasnoyarsk, 660041, Russia
}

Received 05.06.2017, received in revised form 14.06.2017, accepted 15.06.2017

The paper shows the direct application of the European Convention on Human Rights and the implementation of judgments of the European Court of Human Rights by Russian domestic bodies and also by the judiciary. Although judges more often refer to the guidelines of the highest judiciary as the legal basis for direct application, the author claims that the basis is Art. 15 of the Russian Constitution and subsequent legislation. Analyzing decisions of different levels courts, the author suggests theoretical framework of direct application of international law.

The author argues that the main difficulties in implementing convention provisions for Russia are not related to the Convention on the Protection of Human Rights and Fundamental Freedoms as such, but to the interpretation of its norms in the ECtHR judgments. Although most references are limited to a brief reference to more or less relevant provisions of the Convention, many judges are able to interpret the provisions of the European Convention together with the case law of the European Court of Human Rights. The author suggests preserving the dialogue and coordinated interaction of the European (conventional) and national (constitutional) law and order. The deviation from the legal obligation of the ECtHR judgments, demonstrated by the Constitutional Court of the Russian Federation in the recent judgments of the ECtHR in the case of Anchugov and Gladkov (in part) and in the Yukos case (in full), may lead to a breach of the international obligations of the Russian Federation.

Keywords: domestic courts, European Court of Human Rights, European Convention on Human Rights, direct application, implementation of ECtHR judgments, supranational jurisdictions, subsidiarity.

DOI: 10.17516/1997-1370-0090.

Research area: law.

\section{Introduction}

It's almost 20 years since the Russian Federation has ratified the European Convention for the Protection of Human Rights and Fundamental
Freedoms (hereinafter referred to as the European Convention, the Convention), and for this period the Convention and the judgments of the European Court of Human Rights (hereinafter - the ECtHR,

(C) Siberian Federal University. All rights reserved

* Corresponding author E-mail address: tereshkova@list.ru 
the Court), being part of the legal system of the Russian Federation, have become an integral element of legal culture. The value of the European Convention is that it establishes universal standards of human rights and freedoms, that is, that normative minimum, on which the states should orient when recognizing and securing the proclaimed rights. International standards define: (1) a list of human rights and freedoms; (2) their content; (3) permissible restrictions of rights and freedoms; and (4) a mechanism for the protection of rights and freedoms.

Russian citizens actively use the international mechanism for protecting human rights, established in accordance with the European Convention. The statistics of ECtHR illustrates the growth of complaints filed against Russia and since 2012 a high number of judgments against it (Fig. 1).

In 2013, Russia ranked among the 47 countries participating in the Convention, both in terms of the number of complaints filed against it (16,800 complaints) and in the number of final judgments in which human rights violations were recognized. 129 decisions were passed, among them at least one violation was found in 119 cases.

In 2014, Russia remained the leader in the number of final decisions taken against it, in which human rights violations were acknowledged (against Russia, 129 decisions were passed, of which violations were found in 122 cases). In 2015, the ECtHR adopted 116 decisions on cases against Russia, in which violations were found in 109 ; in terms of the number of complaints filed, Russia moved to the second place after Ukraine. In 2016, 228 judgments were filed against Russia (almost twice as much as in 2015); by the number of complaints filed, Russia moved to the 4th place (Fig. 2).

The reduction in the number of complaints in 2015 is due to the decision of the European Court of Human Rights in the case Abramyan and

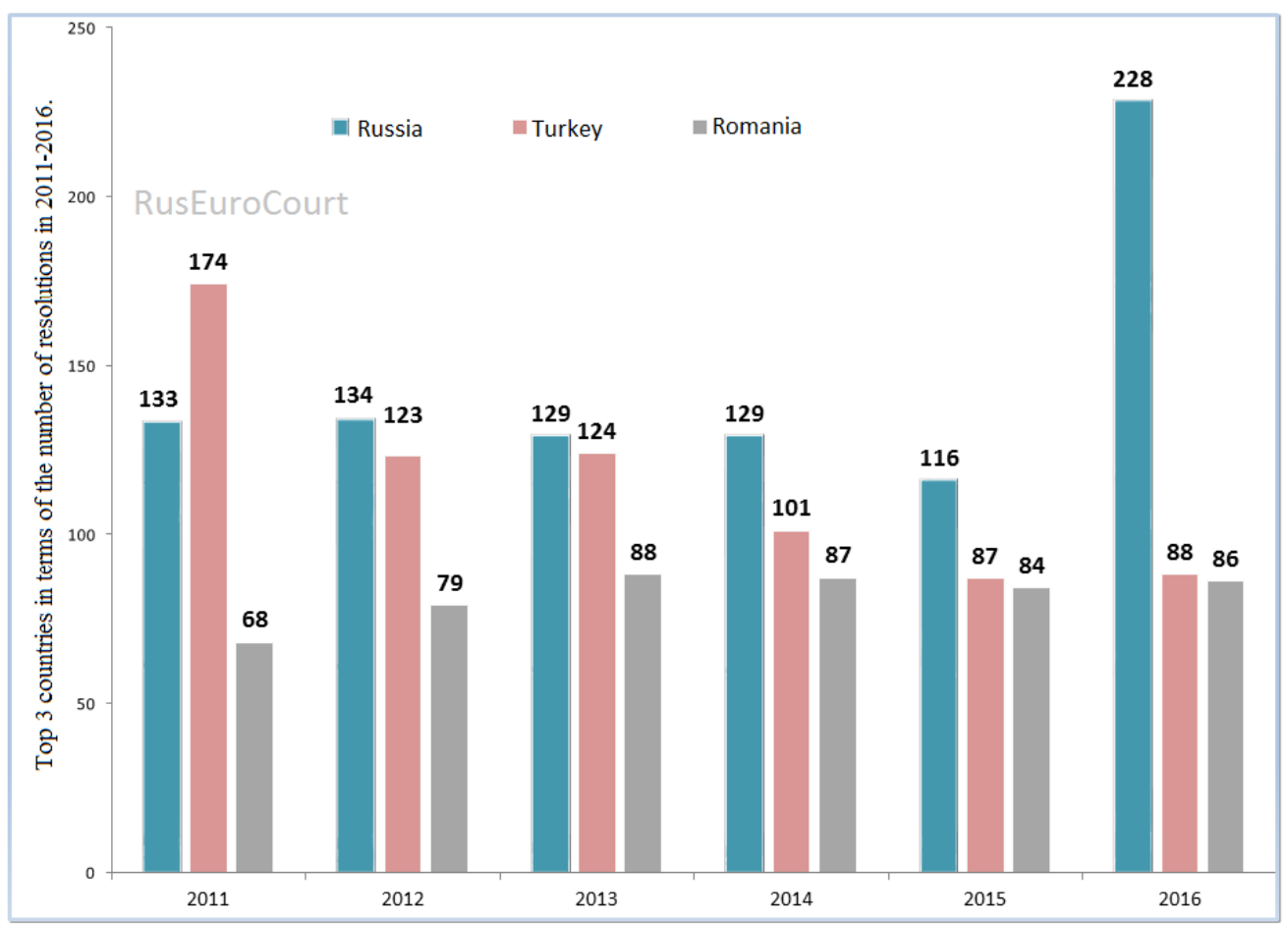

Fig. 1. Top 3 countries in terms of the number of resolutions in 2011-2016 


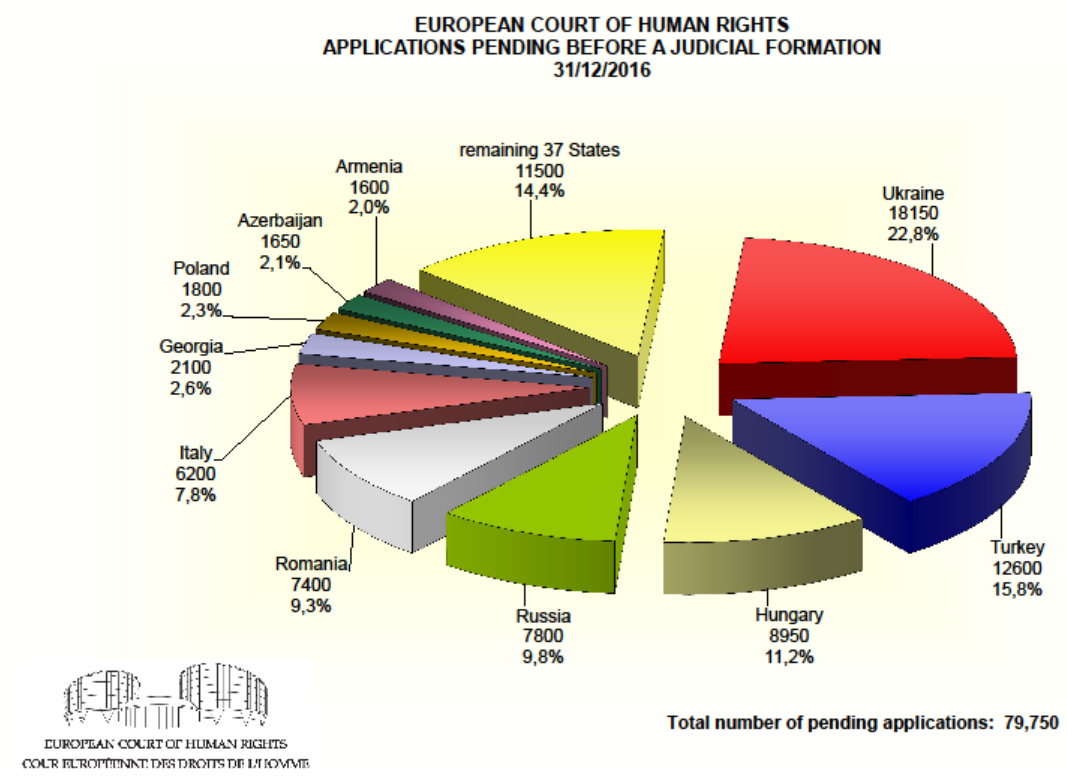

Fig. 2. Number of complaints filed with the ECtHR in 2016

others v Russia (judgment 4 June 2015) where the Court ruled that, in order to file a complaint to the ECtHR, it is mandatory to file with both cassation instances in civil cases operating in Russia from 2012.

However, the importance of the European Convention on the Protection of Rights and Fundamental Freedoms is not only in the consideration of cases of violation of its provisions in the European Court. The effectiveness of international human rights standards increases when they are applied in the sphere of internal jurisdiction (Blackburn and Polakiewicz, 2001; Greer, 2006). Researchers note the special role of national judges in this process, who "are primarily obliged to apply the conventional law in cases and disputes that form the framework of judicial proceedings in all our countries" (O’Boyle et al., 2014, 2016).

The degree of implementation of the European Convention and the ECtHR judgments in the national law of states varies widely. These differences reflect the state's position on the interaction of international and national law. The analysis shows that the constitutional practice of
European states has a clearly expressed tendency to consolidate the correlation of international and domestic law in the constitution. But constitutional provisions in different countries differ significantly from one another. Some countries declare international treaties as part of the domestic law of the country (Bulgaria, Romania, Portugal), part of domestic legislation (Spain). The wording adopted in the Constitution of the Russian Federation, according to which international legal norms are considered as part of the legal system of the state, is the exception, in comparison with the more widespread provisions mentioned above, similar provisions in the constitutions of Lithuania (Article 138) and Estonia (Article 3).

Since the European Convention does not provide for a specific solution to this issue, the European Court does not require that States enforce the Convention within the framework of their national law.

In many states (Austria, Belgium, Germany) the European Convention has the force of law and can be directly invoked in courts, in the Netherlands the Convention takes precedence 
even over the Constitution. In other States (Ireland, United Kingdom) the Convention does not operate directly within the national legal system, courts consider the Convention as an auxiliary tool in interpreting the provisions of the national law. The researchers argue that the European Convention is implemented in the legal system of all participating states (Blackburn and Polakiewicz, 2001; Sweet and Keller, 2008). Even in countries where the Convention is not incorporated into national law, the courts interpret the legislation in such a way as to avoid inconsistency of the European Convention. Although formally the Convention is not part of the legal system, it nevertheless serves as a basis for eliminating uncertainty.

\section{Statement of the problem}

For a long time, the Russian doctrine of international law regarded the fact that the norms of international law created rights and duties only for its subjects, while state bodies, its legal entities and individuals directly did not obey the norms of international law as an axiom (Chernichenko, 1999). The theory of transformation was widespread (Kalanda, 1994; Usenko, 1995). Due to this approach, the interaction of the international treaty and the domestic law was taken into account only in the process of creating norms of national legislation.

A number of scientists, some before the adoption of the new Constitution of the Russian Federation (Ignatenko, 1985), spoke of the direct action of international law in the territory of the state, considering it important to move from the stereotypes of transformation to the direct application of treaties by our courts and state institutions (Danilenko, 1999; Marochkin, 1998, 2012; Tiunov, 1997).

The ratification of the European Convention shifted the emphasis in the debate to the question of whether the norms of the European Convention and the ECtHR decisions could be applied directly in the sphere of intra-state relations.

Many researchers agreed that the European Convention is subject to application by courts as an international treaty of the Russian Federation, by virtue of their inclusion in the Russian legal system (Neshataeva, 1999; Marochkin, 2012). Various positions were expressed about the application of the ECtHR judgments. Without denying that in the judicial practice there are examples of the implementation of the legal positions of the ECtHR that are not binding for Russia by the courts, it was stated that only ECtHR judgments against Russia are subject to application (Zimnenko, 2010). In practice, the courts do not ask themselves whether to implement the ECtHR judgment against Russia or against other countries. They apply a judgments "which they find appropriate in relation to a particular internal matter" (Marochkin, 2012).

The analysis of the practice of the Constitutional Court of the Russian Federation, the Supreme Court of the Russian Federation, the Supreme Commercial Court of the Russian Federation and courts of general jurisdiction (the author conducts a generalization since 1998) allows us to conclude that the ECHR norms and the legal positions of the ECtHR are applied directly in domestic jurisdiction.

The main difficulties in implementing convention provisions for Russia are not related to the European Convention itself, but to the interpretation of its norms in conjunction with the ECtHR judgments. In the absence of a theoretical concept of the direct application of the norms of the European Convention, this applies even more to the application of the legal positions of the ECtHR [the Russian judges have little experience with case law], the judges often incorrectly determine the legal basis for such application, apply not always relevant judgments of the ECtHR, interpret them, based on the meaning of the Russian law, and 
sometimes the reference to convention provisions looks just like a tribute to fashion.

The author shares the view that we need a modern theory that will be "more realistic and more complete" (Wildhaber, 2007), which allows us to determine whether the national courts apply the Convention, based on the wording of the Convention or they take into account the legal positions of the European Court; or whether the provisions of the Convention and the case law of the Court are applied to bring domestic legislation into line with international standards.

\section{Methods}

The author used such general scientific methods as analysis, synthesis, as well as system and comparative-legal methods. When writing the article, the practice of the highest federal judicial bodies (the Constitutional Court of the Russian Federation, the Supreme Court of the Russian Federation, the Supreme Arbitration Court of the Russian Federation (before the reform of the judicial system) was studied and generalized). The generalization conducted by the author touched upon the practice of arbitration courts and courts of general jurisdiction, judicial authorities, law enforcement bodies of the Irkutsk, Moscow, Sverdlovsk, Tyumen, Chelyabinsk regions, the Krasnoyarsk Territory, the cities of Moscow and St. Petersburg. The method of interviewing judges, officials, bailiffs was applied. The author also used her own experience in the implementation of the provisions of the ECHR and the legal positions of the ECtHR in protecting the rights of citizens.

\section{Discussion}

\section{Legal grounds of the implementation} of the European Convention and ECtHR judgments

The legal grounds for the direct application of the European Convention is Part 4 of Art. 15 of the Constitution of the Russian Federation, which regards the international treaties of the Russian Federation as "an integral part of the Russian legal system". The functional purpose of the constitutional norm is manifested in the recognition of the direct effect of international legal norms in the sphere of domestic activities and internal jurisdiction.

On the basis of the Constitution of the Russian Federation, a set of legal acts that aim domestic authorities at direct application of the provisions of the European Convention and the legal positions of the European Court of Human Rights has been established in the Russian Federation.

The analysis of the current Russian legislation confirms this conclusion. Firstly, many laws not only proclaim the norms of international law as an integral part of its legal system, but speak of direct application (action). Part 2, Article 7 of the Civil Code of the Russian Federation, paragraph 3 of Art. 5 of the Federal Law "On International Treaties of the Russian Federation" refer to the direct action of universally recognized principles and norms of international law and international treaties. Secondly, the legislation contains clear instructions on the direct application of international law norms in the administration of justice. Thus, Art. 3 of the Federal Constitutional Law "On the Judicial System", all Russian procedural codes focus courts on the administration of justice through the application of the norms of the Constitution of the Russian Federation, federal laws, and international treaties, international principles and norms (Art. 13 of the Arbitration Procedural Code of the Russian Federation, Art. 1 of the Code of Civil Procedure of the Russian Federation, Art. 1 of the Code of Criminal Procedure of the Russian Federation, Art. 15 of the Code of Administrative Justice). Thirdly, the norms on the activities of various state bodies and sectoral legislation 
among the normative legal acts used in their activities call national laws and international treaties. These are, for example, paragraph 4 of the Regulations on the Ministry of Justice of the Russian Federation, Art. 3 of the Federal Law "On Police", Art. 4 of the Federal Law "On the Federal Security Service". Fourthly, a huge array of legislative acts contains a rule on the priority application of the norms of international treaties; if an international treaty establishes other rules, the rules of the international treaty are applied. Undoubtedly, this kind of wording is intended for law enforcement agencies.

The higher federal courts repeatedly noted the mandatory nature of the ECHR norms and provided explanations on the implementation of the ECtHR judgments in their activities.

A concise explanation of the place of the judgments of the European Court of Human Rights in the Russian legal system was first given in the Information Letter of the Supreme Commercial Court of the Russian Federation of December 20, 1999 "On Basic Provisions Applied by the European Court of Human Rights in the Protection of Property Rights and the Right to Justice". The Supreme Commercial Court of the Russian Federation pointed out that these international legal documents (the European Convention on Human Rights and its Protocols) are binding on the Russian Federation and recommended that the arbitration courts in the administration of justice take into account a number of legal positions developed by the European Court (according to Art. 6 of the Convention and Art. 1 of the Protocol 1).

In one of their first decisions No. 5 of October 10, 2003, the Supreme Court of the Russian Federation gave detailed recommendations on the application of international treaties and explained to lower courts that Russia recognizes the jurisdiction of the European Court of Human Rights as binding on the interpretation and application of the Convention and the Protocols thereto.

In Resolution No. 23 of December 19, 2003, the Plenums of the Supreme Court of the Russian Federation stressed that when delivering a judgement, it is necessary to take into account the judgments of the European Court of Human Rights, which interpreted the provisions of the European Convention to be applied in the present case.

The Resolution of the Plenary Supreme Court of the Russian Federation No. 21 of June 27, 2013 was fully devoted to the application by the courts of the general jurisdiction of the Convention for the Protection of Human Rights and Fundamental Freedoms and its Protocols. The Supreme Court of the Russian Federation pointed out the mandatory character of the legal positions of the ECtHR contained in the final decisions taken against Russian Federation, and explained that the courts should take into account the legal positions of the European Court of Human Rights in the decisions taken against other Contracting states, "if the circumstances of the case before them are analogous to the circumstances that have been the subject of analysis and conclusions of the European Court". The lower courts are advised that "the content of the rights and freedoms provided for by Russian law must be determined taking into account the content of similar rights and freedoms disclosed by the European Court in the application of the Convention and the Protocols to it".

The numerous Resolution of the Plenum of the Supreme Court of the Russian Federation on the consideration of certain categories of cases where judges are given recommendations on the application of certain articles of the European Convention have a practical significance for the courts. The explanations about the application of Art. 10 of the Convention on freedom of expression are given in the Resolution of the Plenum of the 
Supreme Court of the Russian Federation No. 3 of February 24, 2005. When applying measures of restraint, courts are recommended to take into account the legal positions of the ECtHR under Art. 5 of the Convention (Resolution of the Plenum of the Supreme Court of the Russian Federation No. 41 of December 19, 2013) and others.

Note that, referring to the provisions of the ECHR and the judgments of the ECtHR, judges do not call part 4 of Art. 15 of the Constitution of the Russian Federation as a legal basis for the application of the European Convention. In some decisions, as a legal basis, judges refer to the provisions of the sectoral legislation, most often the Civil Code of the Russian Federation. A typical example: the position of the Federal Commercial Court of the Ural Circuit is argued by reference to Art. 1 of Protocol No. 1 to the Convention for the Protection of Human Rights and Fundamental Freedoms, "which is subject to application in accordance with Art. 7 of the Civil Code of the Russian Federation" (decision on the case No. Ф09-2096/03-AK).

In most cases, judges are inclined to argue the application of the ECHR and the European Court judgments in its activities not by provisions of the Constitution of the Russian Federation or by the norms of sectoral legislation, but by guidelines of the highest judiciary, which seems wrong to us. We assert that the Rulings of the Plenum of the Supreme Court of the Russian Federation or the Information Letters of the Supreme Commercial Court of the Russian Federation only inform the courts about the existence of certain legal positions in the practice of the European Court.

\section{Direct effect of the European Convention and implementation of ECtHR judgments}

In theory, the direct effect of the norms of international law in the territory of the state is understood as the application of international legal norms by the state and its bodies without the proclamation of international treaties as sources of law and without "introducing" them into the legal system in any form of modification (Ignatenko, 1985; Tereshkova, 1998).

The direct application of international law in domestic relations is possible without any transformation of them into norms of internal law in the form of:

- priority application of international legal norms (when the law of the Russian Federation or another normative act adopted in the Russian Federation contradicts international legal norms);

- joint application (when in regulation of an issue the norms of international law and the norms of the law of the Russian Federation mutually supplement each other);

- independent application (when there is a gap in the domestic legislation of the Russian Federation).

The complexity of the issue that arises before judges and law enforcement agencies is to establish a hierarchy of legal force in the process of applying the norms of the European Convention and ECtHR judgments in the domestic sphere. On the issue of the correlation between the legal force of norms of international and internal law, the Russian Constitution contains a rule only in relation to the European Convention (as an international treaty). Some scholars do not extend the priority of international treaties to the Constitution of the Russian Federation, believing that "the Constitution is higher, and a hypothetical conflict with an international treaty must be resolved in its favor" (Tuzmuhamedov, 2010). The European Convention and the ECtHR's acts on its interpretation and application, "falling into the Russian legal system, cannot be free from the supremacy of the Constitution" (Aranovskiy and Knyazev, 2017). Others believe that the priority of the Convention "was recognized in relation to all Russian legislation, including the Constitution" (Luk’yanova, 2012). 
The hierarchy of the norms of the legal system provided by the Federal Constitutional Law "On the Judicial System of the Russian Federation" is applied only to the Convention. Are the judgments of the European Court of Human Rights included in the legal system? Finding the place of the European Convention in the Russian legal system does not predetermine the place of the judgments of the European Court among the legal sources of Russia. It is reasonably asserted that "it is a matter of fundamentally different legal acts" (Marchenko, 2006).

The Supreme Court of the Russian Federation stressed that the application of the European Convention "must be carried out taking into account the practice of the European Court of Human Rights in order to avoid any violation of the Convention" (Par. 10 of the Resolution of the Plenum of the Supreme Court of the Russian Federation No. 5, 2003).

It seems that the ECtHR judgments are directly applicable as part of the European Convention. This was said by the Constitutional Court of the Russian Federation, “... not only the Convention for the Protection of Human Rights and Fundamental Freedoms, but also the judgments of the ECtHR - insofar as they ... interpret the content of the rights and freedoms set forth in the Convention ... - are an integral part of the Russian legal system, and therefore should be taken into account by the federal legislator when regulating public relations and law enforcement agencies when applying the relevant norms of law ..." (Par. 2.1 of the Resolution of the Constitutional Court of the Russian Federation of February 5, 2007 No. 2-P).

In practice, courts increasingly make decisions that refer not only to the provisions of the European Convention, but also to the judgments of the European Court of Human Rights. The practice of the Constitutional Court of the Russian Federation is indicative in this respect. Despite the fact that the Federal Constitutional Law "On the Constitutional Court of the Russian Federation" does not contain a clear prescription on the application of international norms in its activities, the Russian Constitutional Court, guided by Part 4 of Art. 15 and Art. 17 of the Constitution of the Russian Federation, uses the European standards of human rights for the argumentation of its decisions. As the Chairman of the Constitutional Court of the Russian Federation noted, the norms of international law are used "as a standard", "to clarify the meaning and significance of the constitutional text" (Zor'kin, 2006).

A special attention should be paid to its decisions, which contain references to the legal positions of the European Court. The Constitutional Court of the Russian Federation was called "the conductor of the legal positions of the ECtHR, its vision of the current state of human rights and freedoms in the Russian legislative and judicial practice" (Tuzmuhamedov, 2010). Analyzing the statistics (Koroteev, 2009, 2013) the researchers note frequent, "more or less relevant", appeal of the Constitutional Court of the Russian Federation to the norms of the European Convention (Burkov, 2013). At the same time, the application of the European Convention by the Constitutional Court of the Russian Federation after moving to St. Petersburg was subject to criticism (Golubok, 2009).

The authors note the shortcomings of the application of the Convention and the judgments of the ECtHR by the Supreme Court of the Russian Federation and district courts of general jurisdiction. The Supreme Court of the Russian Federation, despite the fact that it has referred to the case-law of the ECtHR since 2003, "does so very rarely, with many shortcomings and high selectivity" (Burkov, 2013).

In the decisions of the commercial courts of the subjects of the Russian Federation, the references to the provisions of the European 
Convention are found more often than in judgments of Russian higher federal courts and courts of general jurisdiction. Most of the decisions contain a simple reference to an article of the Convention or a general statement that an action is not inconsistent with the Convention as a whole.

In most cases, judges prefer to argue the decision on the basis of Russian law without resorting to an analysis of the norms of the European Convention or the legal positions of the ECtHR. Courts of general jurisdiction and commercial courts apply to the legal positions of the ECtHR, as a rule, if the parties used them to justify the position. On its own initiative, the court rarely applies the European Convention and judgments of the ECtHR (although the author is familiar with the judgments of the Commercial Court of the Krasnoyarsk Territory and the Third Commercial Court of Appeal, where the judges apply of the legal positions of the ECtHR as the initiator). The references to the European Convention are given, as a rule, in the motivation part of the decision, although there are exceptions (in the operative part).

National judicial decisions cause critical remarks. Even when the court actually applies the ECtHR ruling in the argumentation of its decision, it makes a general reference to the Convention, avoiding references to the legal positions of the ECtHR. I will give a typical example, "From the requirements of a fair court according to Art. 6 of the European Convention on the Protection of Human Rights and Fundamental Freedoms, the public interest in the fight against drug trafficking cannot justify the use of evidence obtained as a result of police incitement ..." (The decision of the supervisory instance court of November 5, 2013, No. 46-Д13-23). The italicized position was formulated by the ECtHR in the case of Vanyan v. Russia (§ 46).

Despite the shortcomings and gaps in the application of the European Convention and the
ECtHR judgments, we affirm that the courts of general jurisdiction and the commercial courts of a different Russian region the latter to the greater extent) have gained positive experience.

In the practice of commercial courts, the references to the legal positions of the European Court are found in cases related to the protection of property rights, the right to a fair trial, in cases of protection of honor and dignity, and tax disputes. The courts of general jurisdiction apply the legal positions of the ECtHR in various categories of cases, when choosing a preventive measure, in assessing evidence obtained as a result of incitement, when deciding on the deportation of a foreign citizen, and others.

In judicial decisions, the European Convention and judgments of the European Court are used as an additional argument, in case of gaps in the Russian legislation they serve as the only basis for the decision of the national court, in case of conflict with the norms of national law the court applies a form of priority application.

The application of the legal positions of the ECtHR requires that the national judges take a creative approach to adjudication. This is especially true of questions of interpretation. National judges are responsible for the correct interpretation and application of the Convention, the provisions of which should be interpreted in conjunction with the judgments of the European Court and in accordance with the purpose and object of the international treaty.

Many national decisions testify to the high qualifications of judges, the ability of judges to work with the case-law of the European Court, the courts apply the relevant legal positions of the ECtHR in their internal affairs and conduct an analysis of the legal positions of the ECtHR expressed in both cases against Russia and other states.

The author's archive contains quite a few court decisions, where the analysis of the 
provisions of the European Convention is given in accordance with the spirit of the Convention and the legal positions of the ECtHR. As an example, I will give an argument in the decisions of the federal court of Sovetsky district of Krasnoyarsk, 2009 (ordinary district court):

"The European Court emphasizes that 'one of the fundamental aspects of the rule of law is the principle of legal certainty, which requires, inter alia, that where the courts have finally determined an issue, their ruling should not be called into question.' (Brumarescu v. Romania).

This principle insists that no party is entitled to seek re-opening of the proceedings merely for the purpose of a rehearing and a fresh decision of the case. 'Higher courts power to quash or alter binding and enforceable judicial decisions should be exercised for correction of fundamental defects. The mere possibility of two views on the subject is not a ground for re-examination. Departures from that principle are justified only when made necessary by circumstances of a substantial and compelling character' (Parolov v. Russia)."

The purpose of giving an overview of the implementation of the provisions of the European Convention in the Russian legal system does not allow us to dwell in more detail on the analysis of the categories of cases in which judges apply the provisions of the European Convention and the ECtHR judgments, the relevance analysis of the references and interpretation of the legal positions of the ECtHR, the analysis of forms of direct application. It will be presented in the next study. Outside the framework is the application of the convention mechanism by the Russian judicial authorities and law enforcement agencies, this is practically an unexamined field [the author conducted interviews with officials of the Krasnoyarsk Territory authorities].

The personal experience of the author allows us to conclude that judges who have been trained in the European Convention interpret it according to the Vienna Convention on the Law of Treaties of 1969, giving the Convention a dynamic or evaluative interpretation (the author has been training the judges of the Krasnoyarsk Territory since 1998 no less than three times a year).

\section{ECtHR and Russian national courts:} dialogue or confrontation?

The characteristics of the issue of the significance of the European Convention and the judgments of the ECtHR would be incomplete without mentioning the latest judgements of the Russian Constitutional Court. The variants for cooperation between the ECtHR and the national courts exemplified by the bodies of constitutional justice have already been the subject of discussion (Garlitcki, 2006). The discussion unfolded with renewed energy after the European Court examined the case of Konstanin Markin v Russia (2010).

The leaders of the Russian state and the judicial authorities said that the national law should be above the ECtHR judgments as "Russia did not transfer the part of its sovereignty to the European Court of Human Rights, allowing to make decisions on changing Russian legislation" (Medvedev as a Russian President, 2010). When determining the boundaries of the ECtHR jurisdiction, one must proceed from the fact that it was Russia that ratified the treaty, which established the ECtHR jurisdiction (Zor'kin, 2010a). It was alleged that "by interfering into the sphere of the Constitutional Court jurisdiction, the ECtHR not only undermines its authority but can also spoil relations with its consistent ally" (Tuzmuhamedov, 2010).

In the opinion of the Chairman of the Russian Constitutional Court, when the ECtHR judgements "directly affect national sovereignty and the fundamental constitutional principles, Russia has the right to develop a protective 
mechanism against such judgments" (Zor'kin, 2010b). The case of Konstanin Markin v Russia (GC, 22.03.12) is exemplified as a case that "goes against the Constitution of the Russian Federation", in the first judgments on which the positions of the ECtHR and the Russian Constitutional Court diverged.

K. Markin, a military intelligence officer, asked for a parental leave to care for a child up to three years, since after the birth of the third child, the couple divorced, and three children remained with the father. After the refusal he turned to the military court. The court dismissed the claim, pointing out that only servicewomen are entitled to receive such leave. The applicant appealed against the judgments believing that the principle of equality between men and women, guaranteed by the Constitution of the Russian Federation, was violated. The applicant applied to the Constitutional Court of the Russian Federation, arguing that the provisions of the Military Service Law relating to parental leave are incompatible with the Constitution of the Russian Federation (equality). The Russian Constitutional Court rejected his application. The European Court found Russia's violation of the prohibition of discrimination (Article 14 of the ECHR).

Note that after the European Court of Human Rights issued a ruling on the case of Konstanin Markin v Russia on June 30, 2011, the State Duma of the Russian Federation received the draft bill of A. Torshin on the priority of the Russian Constitutional Court over the ECtHR. Considering serious public debate, the Lower House of Federal Assembly postponed consideration of the bill. It is interesting that the Committee on Constitutional Legislation which earlier urged the deputies to consider the draft bill at the next meeting asked for a postponement.

$\mathrm{K}$. Markin was actually granted the leave to care for the child, compensation for moral harm awarded by the resolution of the Grand Chamber of the European Court (dated 22.03.2012) was paid.

In accordance with clause 4 , part 4 of Article 392 of the Russian Civil Procedure Code, the ECtHR establishment of the violation of the provisions of the European Convention when the court examines a specific case, in connection with the judgments on which the applicant applied to the European Court, serves as a basis for reviewing judicial decisions that have entered into force for new circumstances.

Despite the provisions of the Russian Civil Procedure Code of April 15, 2013, the Military Court of the Leningradskiy Command refused Markin to reopen the case on new circumstances, considering that any other special measures to implement this judgments are not required. In the Resolution of December 6, 2013, No. 27-П, the Russian Constitutional Court indicated that Article 392 and Article 11 of the Civil Procedure Code of the Russian Federation does not prevent the court of general jurisdiction from commencing the proceedings for reviewing the enforceable judicial decision on new circumstances on the application of a citizen whose complaint to the Russian Constitutional Court on the violation of his constitutional rights and freedoms was previously found as not meeting the eligibility criterion, in connection with the establishment of violation of the provisions of the European Convention by the European Court.

In case if the court of general jurisdiction comes to the conclusion that it is impossible to implement the ECtHR judgment without recognizing that the legal provisions, which the Russian Constitutional Court earlier stated, do not violate the applicant's constitutional rights in a specific case, are not in compliance with the Constitution of the Russian Federation, it [the court] is entitled to suspend the proceedings and apply to the Russian Constitutional Court with a request to verify the constitutionality 
of these legal provisions. Collisions in the interpretation of the European Convention were designated by the Russian Constitutional Court in Resolution No. 21-П of 14.05.2015. According to the Russian Constitutional Court, "the coexistence of European and constitutional legal order is impossible under conditions of subordination, since only dialogue between different legal systems is the basis of their proper balance". Without elaborating on the analysis of Resolution No. 21-П (a number of publications are devoted to it in this issue of this journal), note that references to the case of Görgülü $v$ Germany and the case of Hirst $v$ UK as the cases illustrating a digression from the interpretation of the Convention by the European Court of Human Rights are considered to be not entirely correct. I argue that these cases, on the contrary, illustrate the search for a compromise. The judgment of the German Federal Constitutional Court enshrined the rule of domestic law interpretation, including the Constitution, in accordance with the international obligations of the state. Although many years later (the ECtHR judgment was made in 2005), the Great Britain nevertheless developed Draft Voting Eligibility (Prisoners) Bill (2013).

The dialogue of the constitutional and convention jurisdictions was significantly influenced by the ECtHR judgment on the case Anchugov and Gladkov v Russia, 04.07.2013.

Russian citizens - Anchugov, convicted of murder, theft and fraud to capital punishment (later commuted to fifteen years' imprisonment), and Gladkov, convicted of murder, robbery, participation in an organized criminal group and resistance to law enforcement officers to capital punishment (later commuted to fifteen years' imprisonment), were debarred from voting.

ECtHR held that the ban on voting set by part 3 of Article 32 of the Russian Constitution for convicts contradicts to Article 3 of Protocol No. 1 to the Convention.
By adopting Resolution No. 12-П of April 19, 2016, the Russian Constitutional Court for the first time implemented the powers provided by amendments to the Federal Constitutional Law "On the Russian Constitutional Court" (Articles 104.1, 104.2 and 104.3), considering the issue of the possibility of implementing the decisions of the interstate body for the protection of human rights and freedoms (namely, the ECtHR judgment on the case of Anchugov and Gladkov v Russia).

The Russian Constitutional Court indicated that the implementation of this judgments of the ECtHR is impossible, as Article 32 of the Russian Constitution establishes an imperative ban of the voting rights of convicts. It is impossible to adopt general measures that involve changes into Russian legislation (and, thus, a change in the court practice based on it), which would limit the voting rights of not all convicts serving sentences in the places of deprivation of liberty on the verdict of a court.

However, in the second paragraph of the operative part of the judgment, the Russian Constitutional Court, in fact, proposed measures for implementation, indicating that the courts can interpret the Criminal Code of the Russian Federation in such a way that debarring from voting is appointed by the courts only if a less severe form of punishment cannot ensure the achievement of punishment objectives. According to the position of the Russian Constitutional Court, the implementation of general measures in this case will be provided by the courts in such a way as to ensure fairness, proportionality and differentiation of the application of restrictions on electoral rights in sentencing.

The Russian Constitutional Court also pointed out that "the federal legislator is qualified to consistently implement the principle of humanism in criminal law, to optimize the system of criminal punishments, including by 
transferring certain regimes of serving sentences to alternative types of punishment, although related to the forced restriction of convicts' liberty, but not entailing restrictions on their voting rights".

In the ECtHR' judgment there was no direct requirement to amend the Constitution of the Russian Federation, the European Court held that "different approaches are possible to resolve the issue of the right of the convicted prisoners to vote". The state has the right to decide independently whether compliance with Article 3 of Protocol No. 1 to the Convention can be reached "through some form of political process or by interpreting the Russian Constitution by the competent authorities - the Russian Constitutional Court in the first place - in harmony with the Convention in such a way as to coordinate their effects and avoid any conflict between them" (§ 111, the case of Anchugov and Gladkov v Russia).

With the adoption of the judgments of the Russian Constitutional Court of 19 January 2017 No. 1-П, there was a pause in the established dialogue between the ECtHR and the Russian Constitutional Court. The Russian Constitutional Court found it impossible to implement the ECtHR judgment on YUKOS case of July 31, 2014 on the following grounds: the facts of fraudulent behavior of the members of the company's management and some of its shareholders, the "law-destroying effect" of the company's activities, the existence of unliquidated obligations at the moment of liquidation, including before the budget, for an amount significantly exceeding the amount of the award. The Russian Constitutional Court considered that execution of the ECtHR judgment of the YUKOS case would violate the constitutional principles of equality and fairness in tax legal relationship.

The Russian Constitutional Court disagreed with the position of the European Court on the case, pointing out that the latter "does not always take into account the Russian "constitutional identity" and the historical aspects of the problem that are at the basis of the dispute. There have already been concerns in the doctrine that the doubts about the correctness of the ECtHR's position "may affect the desire of the national courts to implement the ECtHR judgments fully" (Garlitcki, 2006).

The lack of dialogue will have a negative impact on the efficiency of the norms of the Convention on the Protection of Human Rights and Fundamental Freedoms in the domestic law and order and, consequently, on the effectiveness of the whole system of protection of human rights in general.

To build a constructive dialogue, several circumstances are important. Firstly, the norms of any international treaty are obligatory for its participants. The participant "cannot refer to the provisions of its domestic law as an excuse for not fulfilling the treaty" (Article 27 of the Vienna Convention on the Law of Treaties of 1969). As early as in 1932, the judge of the Permanent Court of International Justice expressed the position that “.... the state has no right to refer to ... its own constitution with the aim of avoiding obligations imposed on it in accordance with international law or existing treaties" (P.CIJ, 1932).

Moreover, in accordance with Article 46 of the European Convention, Russia was bound by the obligation "to execute the final judgments of the Court in any case in which it is a party". The failure to execute the ECtHR judgment may become "the cause of the constitutional crisis in the country" (Dzehtsiarou and Timofeev, 2016), as the decision of the Grand Chamber of the ECtHR is not subject to revision and the obligation to implement it will persist. That was confirmed by the Committee of Ministers of the Council of Europe, which functions include monitoring the implementation of the ECtHR judgments, at the meeting held from 7 to 10 March 2017. 
The Deputies expressed "serious concern at the non-implementation of the judgment of 31 July 2014" and firmly reiterated the unconditional obligation assumed by the Russian Federation under Article 46 of the Convention to abide by the judgments of the European Court. The Committee of Ministers urged to be informed about all relevant steps towards an appropriate solution and call upon the Russian Federation to continue the dialogue. The Committee is to resume consideration of this case in September 2017.

Secondly, the failure to implement the judgement is incompatible with the principle of the rule of law, which the bodies of justice, both international and domestic ones, are guided by. The right to a fair trial guaranteed by both the European Convention and national legislation "would be illusory if domestic legal system allowed a final, binding judicial decision to remain inoperative to the detriment of one party" (Burdov v Russia, 2002, para. 34).

Lastly, the interaction is determined by the understanding of the fact that domestic and international judicial bodies ultimately share the common goal of protecting human rights.

It seems necessary to make every effort to seek for a compromise and dialogue with the European Court of Human Rights. And this is a two-way process.

\section{Conclusion}

The analysis of the legislation and judicial practice allows drawing a conclusion that in Russia legal bases for the direct application of the European Convention, combined with the caselaw of the ECtHR are established.

Domestic authorities and courts have the right to apply the provisions of the ECHR and the judgments of the European Court of Human Rights in support of their arguments, based on Part 4 of Article 15 of the Russian Constitution, Federal Constitutional Law "On the Judicial System of the Russian Federation" and sectoral legislation.

Although most references are limited to a brief reference to more or less relevant provisions of the Convention, judges are able to interpret the European Convention in the light of the European Court's case-law.

Courts and law enforcement agencies apply the European Convention and the legal positions of the ECtHR for the judgments reasoning in the following forms:

- as the only ground (independent use);

- for additional reasoning (joint application);

- in case of a conflict with the national legislation (priority use).

Courts apply the European Convention taking into account the legal position of the ECtHR for the interpretation of national norms in order to avoid conflict with the Convention.

The Russian authorities, including the judiciary ones, in their activities are bound by both domestic and international law. This is also guided by the norms of international law. According to Article 27 of the Vienna Convention on the Law of Treaties of 1969, "A participant cannot invoke the provisions of its domestic law as an excuse for not fulfilling the treaty". Article 46 of the ECHR emphasize the mandatory nature of the ECtHR judgments.

Recent Resolution of the Russian Constitutional Court 12-П, 21-П and 1-П cannot change the dialogue between the ECtHR and the Russian national courts that started after the accession to the Council of Europe. 


\section{References}

Anagnostou, D., Mungiu-Pippidi A. (2014). Domestic Implementation of Human Rights Judgments in Europe: Legal Infrastructure and Government Effectiveness, In The European Journal of International Law, 25 (1) EJIL, 205-227. DOI:10.1093/ejil/chu001

Aranovskiy K., Knyazev S. (2017). Constitutional Foundation of the Execution of the ECtHR Judgments in the Legal System of the Russian Federation, In Law Enforcement Review, 1 (1), 139-150. DOI:10.24147/2542-1514.2017.1(1).139-150.

Blackburn, R., Polakiewicz, J. (2001). Fundamental rights in Europe, In The ECHR and its.

Burkov, A. (2013). How to Improve the Results of a Reluctant Player: the Case of Russia and the European Convention on Human Rights In Job: Flogaitis-European Court of Human Rights and its Discontents: Turning Criticism into Strength. Chapter 13, 147-157. ISBN 9781782546122, CM/Del/Dec(2017)1280/H46-26. Available at: https://search.coe.int/cm/pages/result_details. aspx?ObjectId $=09000016806$ fad1d

Chernichenko, S.V. (1999). Teoria mezhdunarodnogo prava: Sovremennyi teoreticheskie problemy. $v 2$ tomakh. T. 1. [Theory of International Law: Contemporary Theoretical Problems. In 2 vol. Vol. 1]. M., 336 p.

Danilenko, G.M. (1999). Implementation of international law in CIS states: theory and practice. In European Journal of International Law, 10 (1), 51-69.

Dzehtsiarou, K., Timofeev, M. (2016). Written Views (to the Russian Constitutional Court) on the Merits of the Case Concerning the Request of the RF Ministry of Justice to Resolve the Issue of the Possibility of Enforcing the ECtHR's judgment in the case OAO Neftyanaya Kompaniya "YUKOS" $v$ Russia. Available at: http://www.ksrf.ru/ru/Sessions/Documents/Yukos_Zaklyucheniye_30_11_2016. pdf

European Court of Human Rights. Application No. 11157/04 and 15162/05, Anchugov and Gladkov v. Russia, Judgment of 4 July 2013.

European Court of Human Rights. Application No. 14902/04, OAO Neftyanaya Kompaniya "YUKOS" v Russia. Final judgment, 08 March 2012.

European Court of Human Rights. Application No. 14902/04, OAO Neftyanaya Kompaniya "YUKOS" v Russia. Just satisfaction, 31 July 2014.

European Court of Human Rights. Application no. 30078/06, Konstantin Markin v. Russia [GC], Judgment of 22 March 2012.

Garlitcki, L. (2006). Sotrudnichestvo i konflikt (neskol'ko nablyudenii iz praktiki vzaimodeistviia Evropeiskogo Suda po pravam cheloveka i natsionalnikh organov provosudiia [Cooperation and Conflict (Several Observations from the Practice of Interaction of the European Court of Human Rights and National Bodies of Constitutional Justice], In Doklady. Implementatsiia reshenii Evropeiskogo Suda po pravam cheloveka v praktike Konstitutsionnykh sudov stran Evropy [Collection of Reports. Implementation of Judgments of the European Court of Human Rights in the Practice of Constitutional Courts in Europe]. M., 9-29.

Golubok, S.A. (2009). Evropeiskaia Konventsyia o zashchite prav cheloveka i osnovnikh svobod v postanovleniiakh Konstitutsionnogo suda RF: nachalo peterburgskogo perioda i neskol'ko slov v zachshitu moskovskogo [European Convention for the Protection of Human Rights and Fundamental Freedoms in the Constitutional Court of the Russian Federation: the Beginning of the St. Petersburg 
Period and a Few Words in Defense of the Moscow Period], In Sravnitelnoe Konstitutsionnoe Obozrenie, 6 (79), 150-159.

Gosduma otlozhila rassmotrenie zakonoproekta o prioritete Konstitutsionnogo Suda nad ESPR. [The State Duma Postponed Consideration of the Draft Law on the Priority of the Constitutional Court over the European Court of Human Rights]. Available at: https://www.vedomosti.ru/politics/ news/2011/06/30/gosduma_otlozhila_rassmotrenie_zakonoproekta_o_prioritete_ks

Greer, S. (2006). The European Convention on Human Rights: Achievements, Problems and Prospects.

Judgment of the Russian Constitutional Court of December 6, 2013 No. 27-П "On the Case on the Verification of the Constitutionality of the Provisions of Article 11 and paragraphs 3 and 4 of Part Four of Article 392 of the Code of Civil Procedure of the Russian Federation in Connection with the Request of the Presidium of the Leningrad District Military Court". Available at: https://rg.ru/2013/12/18/ks-dok.html

Judgment of the Constitutional Court of the Russian Federation of April 19, 2016 No. 12-П "On the Case on the Resolution of the Issue of the Possibility of Implementation of the Judgment of the European Court of Human Rights in Accordance with the Constitution of the Russian Federation" of July 4, 2013 on the Case "Anchugov and Gladkov v. Russia" in Connection with Request of the Ministry of Justice of the Russian Federation. Available at: http:/www.consultant.ru/document/cons doc_LAW_197028/

Judgement of the Constitutional Court of the Russian Federation of 14.07.2015 N 21-П "On the case of verification of the constitutionality of the provisions of Article 1 of the Federal Law "On Ratification of the Convention for the Protection of Human Rights and Fundamental Freedoms and its Protocols", paragraphs 1 and 2 of Article 32 of the Federal Law "On International Treaties of the Russian Federation", parts 1 and 4 of Article 11, paragraph 4 of the fourth part of Article 392 of the of Civil Procedure Code of the Russian Federation, Parts 1 and 4 of Article 13, Paragraph 4 of Part 3 of Article 311 of the Arbitration Procedural Code of the Russian Federation, Parts 1 and 4 of Article 15, Part 1 of Article 350 of the Code of Administrative Court Procedure of the Russian Federation and paragraph 2 of the fourth part of Article 413 of the Code of Criminal Procedure of the Russian Federation in connection with the request of a group of deputies of the State Duma. Available at: https://www.consultant.ru/law/hotdocs/43697.html

Judgment of the Constitutional Court of the Russian Federation of 19.01.2017 No. 1-П "On the case on the resolution of the issue of the possibility of implementation of the judgment of the European Court of Human Rights of July 31, 2014 in accordance with the Constitution of the Russian Federation in the case of OAO "Oil Company "YUKOS" v. Russia" in connection with the request of the Ministry of Justice of the Russian Federation. Available at: http:/www.consultant.ru/document/cons_doc_LAW_211287/

Harris, D., O’Boyle M., Bates, E., Buckley, C. Warbrick K. (2014). Law of the European Convention on Human Rights. Third Edition, 1080 p. ISBN: 9780199606399.

Harris, D., O’Boyle M., Warbrick K. (2016). Pravo Evropeiskoi Konventsii po pravam cheloveka [Law of the European Convention on Human Rights]. Third Edition. Translation into Russian. M., 1432 p. ISBN: 9785990564855.

Ignatenko G.V. (1985). Mezhdunarodnoe i sovetskoe pravo: problemy vzaimodeistviia pravovykh system [International and Soviet Law: Problems of Legal Systems Interaction], In Sovetskoe gosudarstvo i pravo [Soviet State and Law], 1, 73-81. 
Information Letter of the Supreme Arbitration Court of the Russian Federation of December 20, 1999. On the Main Provisions Applied by the European Court of Human Rights in the Protection of Property Rights and the Right to Justice (2000). In Bulletin of the Supreme Arbitration Court of the Russian Federation, 2.

Kalanda V.A. (1994). O tranformatsii norm mezgdunarodnogo prava $\mathrm{v}$ pravovuyu sistemu Rossiiskoi Federatsii (konstititsionno-pravovoi analiz) [About Transformation of international norms into Russian Legal System (constitutional legal analysis], In Moscow Journal of International Law, 4, 12-27.

Koroteev, K. (2009). Evropeiskaia Konventsyia o zashchite prav i osnovnykh svobod cheloveka v postanovleniiakh Konstitutsionnogo suda RF (Moskovskii period) [European Convention for the Protection of Human Rights and Fundamental Freedoms in Judgments of the Constitutional Court of the Russian Federation (Moscow Period)], In Sravnitelnoe Konstitutsionnoe Obozrenie, 4 (71), 92-120.

Koroteev, K. (2013). Mesto Evropeiskoi Konventsii o zashchite prav i osnovnih svobod cheloveka v argumentatsii reshenii Konstitutsionnogo suda RF: ot pereezda v Sankt-Peterburg do dela Konstantina Markina [Place of the European Convention on Protection of Human Rights and Fundamental Freedoms in the Argumentation of the Russian Constitutional Court's Judgments: from its Move to St. Petersburg to the case of Konstantin Markin], In Sravnitelnoe Konstitutsionnoe Obozrenie, 4 (95), 68-83.

Luk'yanova, E. (2012). ESPCH i Konstitutsionnyi sud RF: Konflit tolkovanii [ECtHR and the Constitutional Court of the Russian Federation: Conflict of Interpretations]. Available at: www. igzakon.ru/magazine/article-pdf/?id=3812.

Marchenko, M.N. (2006). Iuridicheskaia priroda i kharakter reshenii Evropeiskogo Suda po pravam cheloveka [The Legal Nature and Character of Judgments of the European Court of Human Rights], In Gosudarstvo i pravo [State and Law], 2, 11-19.

Marochkin, S.Y. (1998). Deistvie norm mezgdunarodnogo prava v provovi sisteme Rossiiskoi Federatsii [Application of International Norms in Russian Legal system]. Tuymen, 199 p.

Marochkin, S. (2012). International Law in the Russian Courts in Transitional Situation. (February 29, 2012), In Intersentia. Series on transitional justice, 9. Available at SSRN: https://ssrn. com/abstract $=2555409$

Medvedev D. (2010). Rossia ne pozvolyaet ECtHR vinisit resheniay menyaushchie zakoni [Russia will not allow the ECtHR to make judgments that change its laws]. Available at: https://ria.ru/ politics/20101211/307384165.html

Mezhdunarodnoe pravo [International Law] (1995), In Uchebnik pod red. Ignatenko G.V. [Textbook Ed. by G.V. Ignatenko and O.I. Tiunov]. M., 399 p.

Neshataeva, T.N. (1999). O kompetentsii Evropeiskogo Suda po pravam cheloveka v ontoshenii imushchestvennih prav [On the Competence of the European Court of Human Rights in Respect of Property Rights], In Vestnik VAS RF, 4, 93-97.

Nollkaemper, A. (2014). The Duality of Direct Effect of International Law, In Eur J Int Law, 25 (1), 105-125. DOI: 10.1093/ejil/cht085

Sweet, A.S., Keller, H. (2008). The Reception of the ECHR in National Legal Orders, In Faculty Scholarship Series, 89. Available at: http://digitalcommons.law.yale.edu/fss_papers/89

On the Ratification of the Convention for the Protection of Human Rights and Fundamental Freedoms and the Protocols Thereto. Federal Law of 30.03.1998, In Collection of Legislative Acts 
of the Russian Federation, No. 14. Article 1514. Available at: http://www.consultant.ru/document/ cons_doc_LAW_18263/

Resolution of the Plenum of the Supreme Court of the Russian Federation No. 5 of 10.10.2003 "On Application of General Principles and Norms of International Law and International Treaties of the Russian Federation by the Courts of General Jurisdiction". Available at: https://rg.ru/2003/12/02/ pravo-doc.html

Resolution of the Plenum of the Supreme Court of the Russian Federation No. 23 of December 19, 2003 “On the Judgment”. Available at: http://base.garant.ru/58050284/\#ixzz4ieyaFv71

Resolution of the Plenum of the Supreme Court of the Russian Federation No. 3 of February 24, 2005 "On Judicial Practice in Cases of Protection of Honor and Dignity of Citizens, as Well as Business Reputation of Citizens and Legal Entities". Available at: http://www.consultant.ru/document/ cons_doc_LAW_52017/

Resolution of the Plenum of the Supreme Court of the Russian Federation No. 21 of June 27, 2013 "On the Application of the Convention for the Protection of Human Rights and Fundamental Freedoms by the Courts of General Jurisdiction of November 4, 1950 and the Protocols Thereto". Available at: https://rg.ru/2013/07/05/konvencia-dok.html

Resolution of the Plenum of the Supreme Court of the Russian Federation No. 41 of December 19, 2013 (amended on May 24, 2016) "On the Practice of the Courts Applying Legislation on Preventive Measures in the Form of Detention, Home Arrest and Bail". Available at: http://www.consultant.ru/ document/cons_doc_LAW_156184/

Tereshkova, V.V. (1998). Primenenie norm mezhdunarodnogo prava $v$ sudebnoi sisteme Rossiiskoi Federatsii [Application of Norms of International Law in the Judicial System of the Russian Federation], PhD. Ekaterinburg, 229 p.

Tiunov O.I. (1997). Praktika Konstitutsionnogo Suda Rossiskoi Federatsii po voprosam priminenia mezgdunarodnih norm o zashchite prav cheloveka v svete uchastiya Rossii v Sovete Evropi [The practice of applying international norms on the protection of human rights by the Russian Constitutional Court in the light of the participation of Russia in the Council of Europe], In Russian Federation in Council of Europe: issues of application of Human Rights Law, Yekaterinburg, p. 7-9.

Tuzmuhamedov, B. (2010). Evropeiskii Sud zachshitil mnogodetnogo ottsa-ofitsera [The European Court Has Protected a Father-Officer with Many Children], In Nezavisimaya gazeta. Available at: http://www.ng.ru/politics/2010-10-13/3_kartblansh.html

Usenko, E. (1995). Sootnoshenie i vzaimodeistvie mezhdunarodnogo i vnutrigosudarstvennogo prava i Rossiskaia Konstitutsiia [Correlation and Interaction of International and Domestic Law and the Russian Constitution], In Moscow Journal of International Law, 2, 13-28.

Wildhaber, L. (2007). The European Convention on Human Rights and International Law, In International and Comparative Law Quarterly, 56, 217-232. DOI: 10.1093/iclq/lei163

Zimnenko, B, (2010). Mezhdunarodnoe pravo i pravovaya sistema Rossiiskoi Federatsii. Kurs lektsii [International Law and the Legal System of the Russian Federation. The Course of Lectures]. Moscow, Statut, RAP, 416 p.

Zor'kin V. (2006). Rol' Konstitutsionnogo suda RF v realizatsii Konventsii o zashchite prav cheloveka i osnovnykh svobod [The Role of the Constitutional Court of the Russian Federation in the Implementation of the Convention for the Protection of Human Rights and Fundamental 
Freedoms], In Doklady. Implementatsyia reshenii Evropeiskogo Suda po pravam cheloveka v praktike Konstitutsionnih sudov stran Evropy [Collection of Reports. Implementation of Judgments of the European Court of Human Rights in the Practice of Constitutional Courts in Europe]. M., 238 p., 173-182.

Zor'kin V. (2010a). Resheniia ESPCH ne dolzhny zatragivat' suverenitet Rossii. Vystuplenie na XIII mezhdunarodnom forume po konstitutsionnomu pravosudiu. [The ECtHR' Judgments Should not Affect the Sovereignty of Russia. Speech at the 8th International Forum on Constitutional Justice]. Available at: http://rapsinews.ru/judicial_news/20101119/251066146.html

Zor'kin V. (2010b). Predel ustupchivosti [The limit of Compliance], In Russian Newspaper (29.10.2010). Available at: https://rg.ru/2010/10/29/zorkin.html

\title{
Значение и действие Европейской конвенции о защите прав и основных свобод человека и постановлений Европейского суда по правам человека в правовой системе Российской Федерации
}

\author{
В.В. Терешкова \\ Сибирский федеральный университет \\ Россия, 660041, Красноярск, пр. Свободныий, 79
}

Статья посвящена непосредственному применению Европейской конвенции о правах человека и постановлений Европейского суда по правам человека российскими внутригосударственными органами, включая судебные. По мнению автора, правовой основой непосредственного применения выступает cm. 15 Конституции РФ и последующее законодательство. Однако судьи в качестве правового основания ссылаются на разъяснения высших судебных органов. Анализируя судебную практику, автор выделяет формы непосредственного применения.

Автор утверждает, что основные трудности имплементаиии конвенщионных положений для России связаны не с самой Конвенцией о защите прав человека и основных свобод как таковой, а с толкованием ее норм в постановлениях ЕСПЧ. Несмотря на то, что большинство ссылок ограничено кратким упоминанием более или менее соответствующих положений Конвениии, многие судьи умеют толковать положения Европейской конвенции совместно с прецедентной практикой Европейского суда.

Автор приходит к выводу о необходимости диалога и взаимодействия Европейского суда по правам человека и национальных судов. Отступления от правовой обязательности постановлений ЕСПЧ, продемонстрированные Конституционным судом РФ в недавних постановлениях, может привести к нарушению международных обязательств Российской Федерации.

Ключевые слова: национальные суды, Европейский суд по правам человека, Европейская конвенция о правах человека, непосредственное применение, имплементация решений ЕСПЧ, наднациональная юрисдикция, субсидиарность.

Научная специальность: 12.00.00 - юридические науки. 